\title{
PENGEMBANGAN BAHAN AJAR LKS MENULIS PANTUN BERBASIS KEARIFAN LOKAL SISWA KELAS VII SMP XAVERIUS TUGUMULYO
}

\section{Agung Nugroho*, Dian Ramadan Lazuardi, Sri Murti}

Program Studi Pendidikan Bahasa dan Sastra Indonesia, STKIP PGRI Lubuklinggau, Indonesia

*Corresponding author: agung.nugroho12354@gmail.com

\section{INFORMASI ARTIKEL}

\section{ABSTRAK}

\section{Sejarah Artikel \\ Diterima: $1 / 4 / 2019$ \\ Direvisi: $19 / 6 / 2019$ \\ Disetujui: 19/6/2019 \\ Kata Kunci: \\ Pengembangan \\ Bahan Ajar \\ Menulis Pantun}

Tersedia Daring: 25/6/2019

Keywords:
Development
Learning Materials
Writing Pantun

Penelitian ini bertujuan untuk (1) mendeskripsikan proses mendesain dan mengembangkan bahan ajar Bahasa Indonesia pada pokok bahasan menulis pantun siswa kelas VII SMP Xaverius Tugumulyo (2) mendeskripsikan bahan ajar menulis pantun kelas VII SMP Xaverius Tugumulyo yang valid, praktis, dan efektif. Penelitian ini berdasarkan hasil observasi terhadap kendala yang dialami guru dan siswa di dalam penulisan pantun. Metode yang digunakan penelitian Research and Development (R\&D) dan digunakan model Dick \& Carey yang terdiri dari 10 tahap, namun dibatasi sampai 8 tahap yaitu: (1) analisis kebutuhan dan tujuan; (2) analisis pembelajaran; (3) analisis pembelajar (siswa) dan konteks; (4) merumuskan tujuan performansi; (5) mengembangkan instrumen; (6) mengembangkan strategi pembelajaran; (7) mengembangkan dan memilih bahan pembelajaran; (8) merancang dan melakukan evaluasi formatif. Penelitian yang telah dilakukan ini menghasilakan produk baru berupa bahan ajar LKS menulis pantun. Dari hasil one to one diketahui tergolong baik dengan persentase $91,25 \%$. Nilai postes $t_{\text {hitung }}$ sebesar 31,465 , selanjutnya mencari $t_{\text {tabel }}$ dengan tabel nilai-nilai dalam distribusi $t$. Taraf signifikan $\alpha=0,05$ dan derajat kebebasan $(\mathrm{dk}=\mathrm{df}) 22$, maka diketahui $t_{\text {tabel }}=2,074$. Berdasarkan kriteria pengujiannya yaitu jika $t_{\text {hitung }} \geq t_{\text {tabel }}$ berarti Ho ditolak dan Ha diterima, begitupun sebaliknya jika $t_{\text {hitung }}<\mathrm{t}_{\text {tabel }}$ berarti Ho diterima dan Ha ditolak. Berdasarkan penghitungan di atas yaitu $t_{\text {hitung }} \geq t_{\text {tabel }}(31,465 \geq$ 2,074). Dengan Signifikan sebesar 0,0001 yang berarti lebih kecil dari 0,05 , maka terjadi hubungan yang signifikan. Dengan demikian bahan ajar bisa menulis pantun telah, valid, praktis dan efektif.

\section{ABSTRACT}

This study aims to (1) find out the process of developing Indonesian language teaching materials on the subject of writing pantun for seventh grade students of SMP Xaverius Tugumulyo (2) describing the teaching materials which are valid, practical, and effective. This research is driven from the results of observations in which there are obstacles experienced by teachers and students in writing pantun. The method used is Research and Development (R \& D) research. The research also employs the Dick \& Carey's model which is limited to 8 stages, namely (1) need and objective analysis; (2) learning analysis; (3) learners (students) and context analysis; (4) performing goal formulation; (5) instrument development; (6) learning strategies 


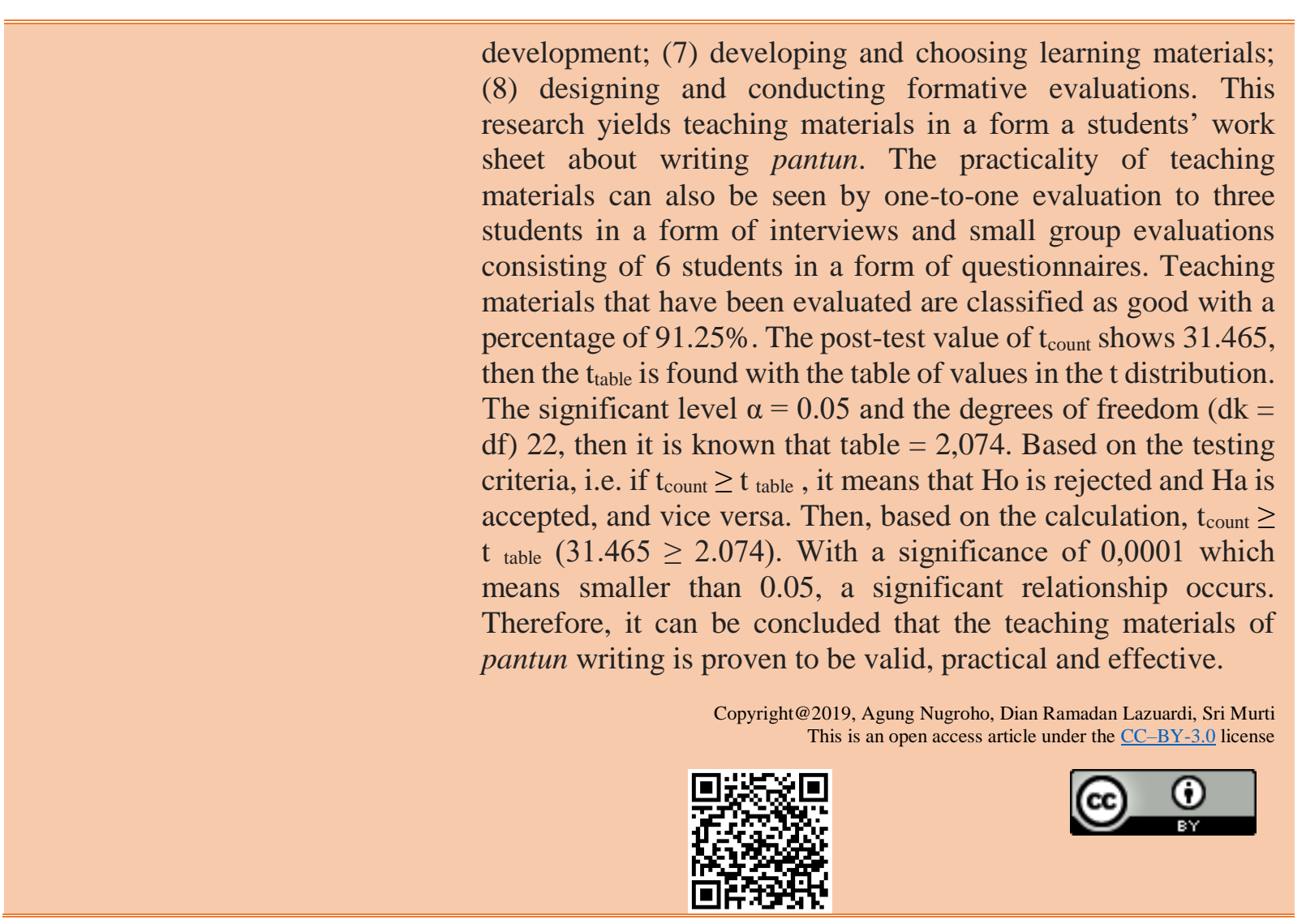

\section{PENDAHULUAN}

Materi sangat berperan penting dalam kegiatan pembelajaran yang sedang berlangsung. Salah satu materi pembelajaran yang ada pada silabus kelas VII SMP membahasa tentang pantun. Dengan cakupan tersebut maka seorang pendidik harus menjelaskan materi pantun secara tuntas. Mulai dari pengertian pantun, jenis-jenis pantun, dan sampailah pada langkahlangkah menulis pantun. Tafifin (2017) menyatakan bahwa pantun mempunyai arti ucapan yang teratur, pengarahan yang mendidik. Selain itu, pantun juga dapat dimaknai sebagai sindiran. Pada mulanya, pantun adalah senandung atau puisi yang dinyanyikan dan digunakan sebagai bahasa pengantar atau bahasa pergaulan". Sugiarto (2011) menjelaskan bahwa pantun merupakan bentuk puisi asli Indonesia (Melayu), namun istilah pantun menjadi perdebatan sebagian pengamat sastra". Pantun disebut puisi lama atau puisi rakyat karena pantun diciptakan oleh rakyat dan dipakai untuk berbagai keperluan rakyat (Khoirotunnisa, Hasanah, \& Dermawan, 2018). Pantun merupakan sebuah materi yang ada pada kegiatan pembelajaran di SMP siswa kelas VII. Pantun sangat digemari siswa, karena dapat mengunggapkan isi hati seseorang dengan cara membuat empat baris yang penuh dengan makna. Hanya terdapat kendala yang dialami guru dan siswa dalam penulisan pantun. Guru yang mengajar mata pelajaran bahasa Indonesia kesusahan mencari referensi yang lengkap dalam penulisan pantun. Referensi yang digunakan saat ini hanya membahas pengertian pantun dan hanya beberapa contoh pantun. Bahan ajar sebagai sumber yang digunkan kurang lengkap mengenai langkahlangkah menulis pantun, sedangkan siswa membutuhkan cara penulisan pantun yang mudah untuk dimengerti, beserta contoh-contoh yang riil (Prasaja, 2016). Contoh pantun yang ditampilkan dalam buku yang digunakan hanya membahas pantun secara luas tanpa menspesifikasikannya. Padahal siswa ingin contoh pantun yang kalimatnya mudah dimengerti dan mudah diaplikasikan. Berangkat dari kondisi tersebut, peneliti ingin mengembangkan 
bahan ajar LKS menulis pantun berbasis kearifan lokal yang mengaitkan dengan budaya lokal serta melibatkan pengetahuan siswa.

Berdasarkan pendapat di atas, diketahui bahwa siswa membutuhkan bahan ajar khusus untuk menulis pantun. Penulis termotivasi untuk mengembangkan bahan ajar menulis pantun berbasis kearifan lokal. Bahan ajar yang dikembangkan berbentuk bahan ajar LKS (Lembar Kerja Siswa). LKS adalah salah satu bahan ajar yang mempunyai peran penting dalam pencapaiaan keberhasilan proses belajar mengajar" (Qomario \& Agung, 2018). Sejalan dengan itu, Sagita (2018) mengatakan LKS juga merupakan salah satu sarana untuk membantu dan mempermudah kegiatan belajar mengajar. LKS yang penulis kembangkan membahas pengertian pantun, contoh-contoh pantun, serta langkah penulisan pantun berbasis kearifan lokal.

Keberadaaan bahan ajar sangat membantu dalam kegiatan belajar mengajar, agar materi lebih tersampaikan dengan baik kepada siswa. Keberadaan bahan ajar membuat siswa lebih tertarik untuk mempelajari materi yang diajarkan oleh guru. Arsanti (2018) mengatakan bahwa bahan ajar memiliki peran yang sangat penting dalam keefektifan pembelajaran. Sejalan dengan pendapat Yaumi (2016) bahwa bahan ajar dipandang sebagai materi yang disediakan dalam kegiatan pembelajaran yang mencakup buku teks, video dan audiotapes, softwere computer, dan alat bantu visual". Penelitian relevan yang mengangkat Pengembangan Bahan Ajar Menulis Pantun Menggunakan Media Mencari Pasangan Kartu pada Siswa Kelas VII SMP Negeri 12 Langsa yang dilakukan oleh (Hidayat, 2018), Pengembangan Bahan Ajar Menulis Pantun Bermuatan Nilai Budaya dengan Strategi Pohon Kata untuk Siswa Kelas VII (Khoirotunnisa et al., 2018), dan Pengembangan Materi Ajar Sosiologi tentang Mitigasi Bencana Berbasis Kearifan Lokal di Kota Padang (Erianjoni, 2018). Ketiga penelitian tersebut memiliki persamaaan dalam hal pengembangan bahan ajar dan materi ajar, sedangkan ketiganya memiliki perbedaan dalam hal penggunaan media, strategi, dan muatan yang terkandung di dalam bahan ajarnya. Dari ketiga kajian yang telah dilakukan tersebut belum pernah dilakukan pengembangan bahan ajar LKS menulis pantun berbasis kearifan lokal. Oleh karena itu, penelitian ini layak dilakukan karena berbeda dengan ketiga kajian yang pernah dilakukan sebelumnya. Berdasarkan uraian di atas, penulis mengembangkan bahan ajar menulis pantun berbasis kearifan lokal di SMP Xaverius Tugumulyo.

\section{METODE}

Pengembangan model bahan ajar yang peneliti gunakan, menganut langkah-langkah pengembangan model bahan ajar menurut Dick \& Carey seperti pada Gambar 1, yang terdiri dari sepuluh langkah meliputi (1) analisis kebutuhan dan tujuan; (2) analisis pembelajaran; (3) analisis pembelajar (siswa) dan konteks; (4) merumuskan tujuan performansi; (5) mengembangkan instrumen; (6) mengembangkan strategi pembelajaran; (7) mengembangkan dan memilih bahan pembelajaran; (8) merancang dan melakukan evaluasi formatif; (9) melakukan revisi; (10) evaluasi sumatif (Aji, 2016). 


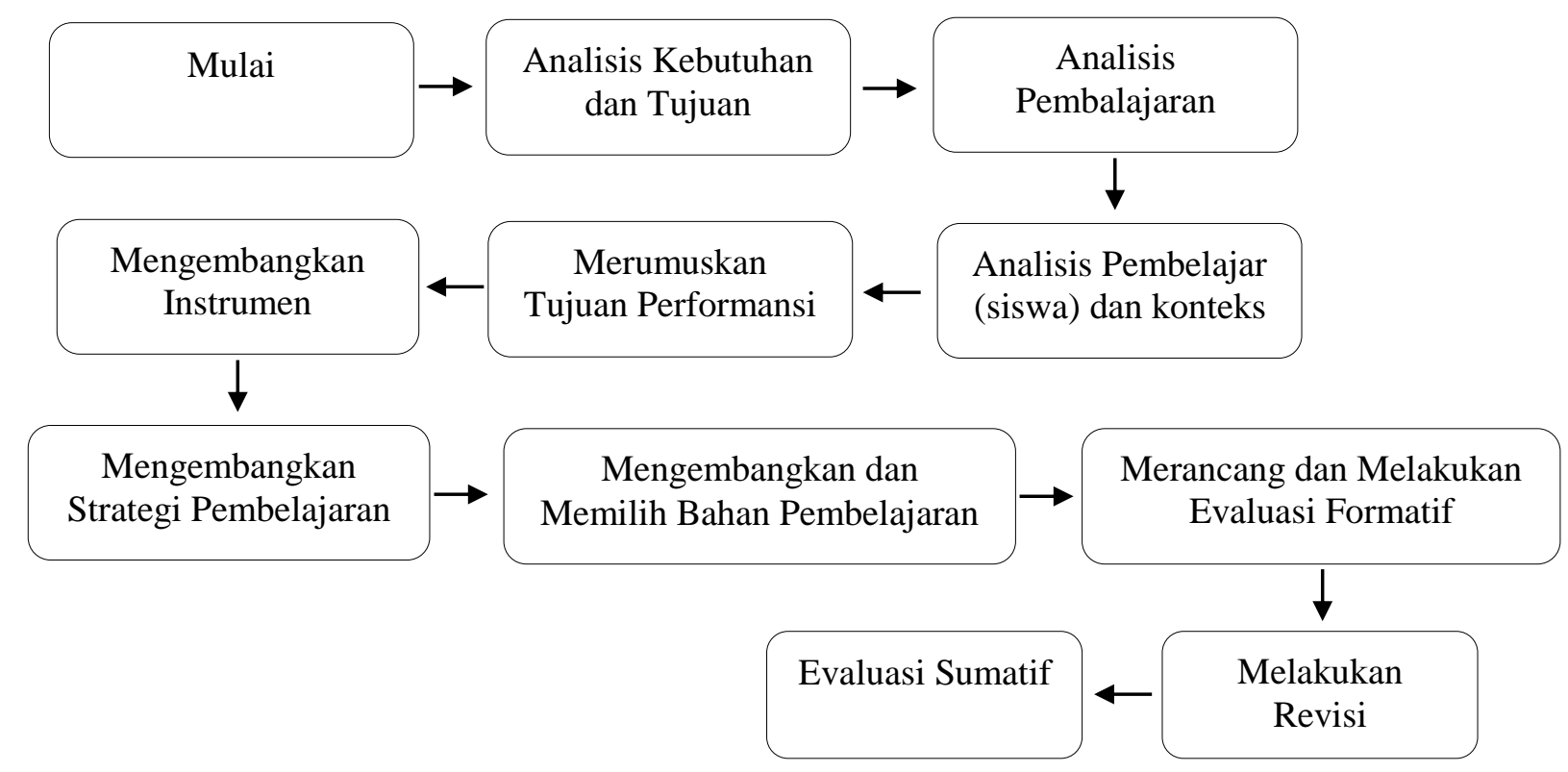

\section{Gambar 1 \\ Model Pengembangan Menurut Dick and Carey}

Perencanaan pengembangan model yang pertama, yaitu merumuskan tujuan performansi atau unjuk kerja yang dilakukan dengan cara menjabarkan tujuan umum ke dalam tujuan yang lebih spesifik berupa rumusan tujuan unjuk kerja. Pengembangan mengidentifikasi standar atau kompetensi dasar yang ada ke dalam rumusan tujuan khusus yang spesifik, terukur, teramati, dan mencerminkan satu jenis perilaku yang diukur. Adapun kegiatan pengumpulan data meliputi (1) implementasi LKS, (2) validasi, (3) evaluasi, dan (4) revisi LKS, keempat tahapan tersebut dijabarkan sebagai berikut.

\section{Implementasi LKS}

Setelah melakukan revisi dari desain produk, selanjutnya produk berupa LKS (Lembar Kerja Siswa) diujicobakan atau diimplementasikan pada siswa kelas VII SMP Xaverius Tugumulyo tahun ajaran 2018-2019. Hal ini bertujuan untuk mengetahui produk bahan ajar menulis pantun, apakah bahan ajar menulis pantun tersebut mampu meningkatkan minat belajar siswa kelas VII SMP Xaverius Tugumulyo tahun ajaran 2018-2019. Sulton (2016) merekomendasikan suatu proses evaluasi formatif yang terdiri dari tiga langkah yaitu; (1) uji coba prototipe bahan secara perorangan (one-to-one triying out). Uji coba tersebut dilakukan pada subjek 1-3 orang. Setelah melakukan uji coba perorangan maka pengembang melakukan revisi produk berdasarkan masukan dari hasil penilaian atau uji validasi. (2) Uji coba kelompok kecil (small group tryout) melibatkan subjek yang terdiri dari 5-6 subjek. Hasil uji coba kelompok kecil ini dipakai untuk melakukan revisi produk sesuai masukan yang diberikan oleh kelompok sasaran tersebut. (3) Uji coba lapangan (field tryout), melibatkan subjek dalam kelas yang lebih besar yaitu melibatkan subjek 15-30. Hasil uji coba lapangan ini dipakai untuk melalukan revisi produk final.

\section{Validasi}

Langkah validasi merupakan proses kegiatan untuk menilai, apakah rancangan produk berupa metode pengajaran baru secara rasional lebih efektif dari yang lama atau tidak (Sugiyono, 2014). Validasi desain bahan ajar menulis pantun siswa kelas VII SMP Xaverius 
Tugumulyo dilakukan oleh pakar atau orang yang ahli di bidangnya, di antaranya (1) Dr. Rusmana Dewi, M.Pd., (ahli sastra), (2) Dr. Noermanzah, M.Pd., (ahli keterbacaan dan kebahasaan), serta (3) Dodi Mulyono, M.Pd., (ahli desain).

\section{Evaluasi}

Tahap evaluasi memiliki tujuan untuk mengetahui kesalahan atau kekurangan dari rancangan produk. Hasil kekurangan dari produk akan diketahui dari tahap evaluasi. Dengan menilai produk yang telah dibuat berdasarkan angket pada siswa serta masukan dari validator.

\section{Revisi LKS}

Kegiatan revisi adalah perbaikan terhadap kelemahan produk yang telah dibuat, berdasarkan hasil dari evalausi, sehingga kelemahan dari produk ataupun kesalahan dapat diperbaiki.

Teknik analisis data dalam penelitian ini dilakukan dengan menganalisis angket siswa, dengan mengikuti langkah-langkah yang meliputi (1) memberikian skor dari setiap butir pertanyaan dengan beberapa kriteria. Pemberian skor data angket setiap butir pertanyaan berdasarkan pada konversi nilai dan skala sikap, (2) menjumlahkan skor dari setiap butir pertanyaan, (3) menghitung skor total rata-rata dari setiap aspek, (4) mengubah skor rata-rata menjadi nilai dengan kategori data kualitatif, (5) konversi data kuantitatif menjadi data kualitatif. Konversi tersebut berpatokan pada tabel konversi data kuantitatif ke data kualitatif.

Dalam penelitian ini nilai kelayakan ditentukan dengan nilai minimal "C" dengan kategori "cukup". Jika hasil penilaian dari validator, guru, dan siswa memperoleh skor rataratanya minimal dengan nilai "C", maka pengembangan bahan ajar LKS menulis pantun berbasis kearifan lokal untuk siswa kelas VII SMP Xaverius Tugumulyo pada kelas VII ini dianggap "cukup layak digunakan".

Analisis data dalam penelitian ini dituangkan dalam bentuk perhitungan deskriptif dan berbentuk soal uraian mengenai menulis berbentuk pantun. Pada penelitian ini tes kemampuan menulis pantun dilakukan satu kali pada akhir tahap uji lapangan guna mengetahui keberhasilan bahan ajar menulis pantun. Penskoran hasil tes kemampuan menulis pantun berpedoman pada kriteria $4=$ Amat Baik; $3=$ Baik; $2=$ Cukup; $1=$ Kurang.

Nilai reliabilitas dari setiap subjek penelitian yang sudah didapatkan diolah sebagai data. Selanjutnya untuk mengetahui keefektifan suatu produk, maka data pretest dan postest dianalisis dengan paired sample uji-t dengan SPSS 16, untuk mengetahui perbedaan tingkat kemampuan siswa sebelum dan sesudah menggunakan bahan ajar hasil dari pengembangan. Jika hasil perhitungan data signifikan lebih kecil dari alpha value $(0,05)$ dapat dinyatakan telah terjadi perbedaan yang signifikan, maka dapat dikatakan bahwa bahan ajar menulis pantun yang digunakan efektif.

Langkah selanjutnya yaitu melihat kepraktisan bahan ajar pantun. Kepraktisan dapat dilakukan dengan evaluasi one to one dan kelompok besar. One to one dilakukan dengan wawancara dengan tiga orang siswa, yang menjawab pertanyaan tentang kepraktisan bahan ajar menulis pantun. Evaluasi kelompok besar dapat dilakukan dengan memberikan angket kepada semua siswa, yang berkaitan dengan kepraktisan bahan ajar menulis pantun.

\section{HASIL DAN PEMBAHASAN HASIL}

Pengembangan bahan ajar LKS menulis pantun kelas VII SMP Xaverius Tugumulyo melalui tiga tahap meliputi; (1) mengidentifikasi, (2) mengembangkan, serta (3) evaluasi dan 
revisi. Tahap-tahap tersebut dilakukan bertujuan untuk menghasilkan bahan ajar LKS menulis pantun kelas VII SMP Xaverius Tugumulyo yang valid, praktis, dan efektif.

\section{Analisis Kebutuhan dan Tujuan}

Pada tahap ini dilakukan untuk mengidentifikasi tujuan pembuatan bahan ajar dan mengidentifikasi kesenjangan keadaan, serta yang diharapkan untuk mengetahui perubahan pada siswa setelah menggunakan bahan ajar yang dikembangkan melalui langkah kebutuhan pembelajaran berikut.

\section{Mengidentifikasi Tujuan Pembuatan Bahan Ajar}

Tahap ini yang dilakukan dalam mengidentifikasi pengguna yang akan menggunakan bahan ajar LKS menulis pantun yaitu: guru, siswa. Dilanjutkan dengan mengidentifikasi bahan ajar menulis pantun berbasis kearifan lokal yang akan digunakan di kelas VII SMP Xaverius Tugumulyo. Proses identifikasi yang telah dilakukan didapati siswa masih mengalami kesulitan dalam memilih suku kata yang tepat dan sesuai dengan struktur pantun. Kondisi tersebut juga ditunjang dengan masih banyak nilai siswa yang berada di bawah KKM. Degan demikian, dibutuhkan solusi untuk menguraikan permasalahan yang dihadapi dalam pembelajaran menulis pantun di kelas VII SMP Xaverius Tugumulyo. Solusinya dengan menghadirkan bahan ajar menulis pantun yang praktis, efektif, dan dapat meningkatkan minat siswa dalam proses pembelajaran.

\section{Mengidentifikasi Kesenjangan Keadaan Sekarang dan Keadaan yang Diharapkan}

Keadaan sekarang belum adanya bahan ajar khusus yang membahas tentang materi menulis pantun, menjadi satu permasalahan tersendiri dalam proses pembelajaran. Siswa juga kurang berminat dalam mempelajari materi pantun. Keadaan yang diharapkan, yaitu pembelajaran di kelas berjalan dengan efektif dan efisien dengan menggunakan bahan ajar LKS yang berbasis kearifan lokal daerah sekitar. Proses identifikasi dilakukan melalui tiga tahapan yang meliputi (1) identifikasi pembelajaran, (2) analisis pembelajar (siswa) dan konteks, serta (3) merumuskan tujuan performansi, ketiga tahapan tersebut diulas sebagai berikut.

\section{a. Identifikasi Pembelajaran}

Tahap ini dilakukan untuk menentukan keterampilan dan pengetahuan yang diperlukan siswa untuk mencapai kompetensi atau tujuan pembelajaran. SMP Xaverius Tugumulyo telah menggunkan Kurikulum 13 dalam proses pembelajaran. Kompetensi Dasar yang digunakan di kelas VII dengan materi pantun yaitu, (3.13) Mengidentifikasi informasi (pesan, rima, dan pilihan kata) dari puisi rakyat (pantun) yang dibaca dan didengar. Berpasangan dengan Kompetensi Dasar (4.13) Menyimpulkan isi puisi rakyat (pantun, syair, dan bentuk puisi rakyat setempat). Penelitian ini hanya menggembangkan pada bagian KD (3.13) yang berfokus pada pantun yang dibaca dan didengar.

\section{b. Analisis Pembelajar (Siswa) dan Konteks}

Pada tahap ini difokuskan pada pengetahuan dan sikap siswa saat pembelajaran. Siswa di SMP Xaverius Tugumulyo sangat disiplin, begitupula dalam kegiatan belajar di kelas. Kondisi yang demikian dapat dilihat dari sikap siswa yang sangat antusias dan tepat waktu untuk mengikuti pembelajaran. Keberadaan siswa yang aktif menjadi nilai plus tersendiri dalam proses pembelajaran, sehingga menjadikan pembelajaran efektif dan tidak membosankan. 


\section{c. Merumuskan Tujuan Performansi}

Merumuskan tujuan performansi merupakan proses penjabaran tujuan pembelajaran khusus (TIK) dari kompetensi dasar yang merupakan tujuan pembelajaran umum (TIU). TIU dan TIK dirumuskan menggunakan format ABCD (Audience, Behavior, Condition, and Degree). Proses perumusan tujuan performansi dapat dilihat melalui tiga langkah yang terdiri dari (1) mengembangkan instrumen, langkah ini merupakan tes acuan dalam menulis pantun yang dibuat berdasarkan TIK pada TIU. Tes yang diberikan hanya satu soal. Soal-soal latihan yang terdapat pada LKS juga memiliki beberapa latihan pelajaran tentang materi menulis puisi. (2) Mengembangkan metode pembelajaran, metode yang dipilih dan dikembangan dalam bentuk ceramah, metode latihan dan penugasan. Metode ini digunakan untuk memerikan tugas menulis pantun yang ditugaskan pada siswa. Setelah siswa melakukan serangkaian kegiatan dalam membahas meteri menulis pantun, siswa akan diberikan tugas untuk menulis pantun. (3) Mengembangkan dan memilih bahan ajar, bahan ajar yang dikembangkan merupakan bahan ajar yang dapat membantu siswa untuk menulis pantun.

\section{Evaluasi Formatif dan Revisi}

Keberadaan bahan aja yang telah dikembangkan harus melalui tahapan terkahir dalam dalam pengembangan yaitu tahap evaluasi dan revisi. Pada tahap evaluasi dan revisi dilakukan dalam beberapa rangkaian meliputi (1) evaluasi ahli, (2) evaluasi perorangan, (3) evaluasi kelompok kecil, dan (4) uji lapangan. Keempat rangkaian tersebut dijabarkan secara detail sebagaimana berikut.

\section{a. Evaluasi Ahli}

Tahapan evaluasi ahli dilakukan terhadap (1) ahli bahasa, (2) ahli kelayakan media, dan (3) ahli isi. Instrumen yang digunakan adalah angket terbuka berdasarkan indikator dan saran yang dibutuhkan dalam mengembangkan bahan ajar LKS pantun. Hasil evaluasi dari (1) ahli bahasa yang dimbail dari seorang dosen ahli di bidang bahasa lebih menekankan kepada komponen kebahasaan yang meliputi; (a) kesedrahaaan struktur kalimat, (b) bahasa mudah dipahami siswa, (c) kejelasan informasi, (d) penggunaan kaidah bahasa Indonesia, (e) pengguanaaan bahasa secara efektif dan efisien, (f) keterkaitan antar kalimat, antar paragraf, dan antar konsep, (g) kelengkapan pendukung penyajian yang memuat kata pengantar, daftar isi, dan daftar pustaka. Hasil evaluasi dari (2) ahli kelayakan desain yang diambilkan dari seorang dosen yang berkompeten di bidangnya menunjukkan 10 poin penting penilaian yang meliputi; (a) kejelasan tujuan, (b) sistematis/urutan penyajian, (c) pemberian motivasi, (d) interaksi (stimulus dan respon), (e) kelengkapan informasi, (f) ukuran dan jenis huruf, (g) ketepatan ilustrasi gambar, grafik, dan tabel, (h) tampilan fisik, (i) kualitas kertas yang digunakan, dan (j) Cover. Evaluasi terkahir yang dilakukan oleh (3) ahli kelayakan isi/materi. Evaluasi dilakukan dengan menggunakan angket terbuka, sehingga validator dapat memberikan kritik dan saran. Kritik dan saran yang diberikan tersebut dapat digukan sebagai perbaikan bahan ajar LKS menulis pantun. Validasi isi dilakukan oleh Dr. Noermanzah, M.Pd. Komponen yang terdapat pada instrumen kelayakan ini terdiri dari tujuh pertanyaan yang meliputi; (a) sesuai dengan SK, KD, dan Silabus, (b) sesuai dengan kebutuhan siswa, (c) kesesuaian bahan ajar dengan perkembangan siswa, (d) kebenaran substansi materi, (e) kesuaian materi dengan latihan, (f) kesesuaian materi dengan evaluasi, (g) manfaat menambah pengetahuan.

Hasil dari ketiga validator secara keseluruhan dapat dilihat pada Tabel 2. Penilaian dari ketiga ahli validasi terhadap bahan ajar menulis pantun yang sudah diuraikan di atas menunjukan penilaian baik. Rekapitulasi hasil keseluruhan dari tiga validasi ahli dapat dilihat pada penghitungan Persamaan 1. 
Keseluruhan Komponen

Jumlah peryataan

$=24$

Kategori Kriteria

$=5$

Skor Maksimal

Skor Minimal

Skor yang diperoleh

$=24 \times 5=120$

$=24 \times 1=24$

$=91$

Rentang Nilai

$=\frac{120-24}{5}=\frac{96}{5}=19,2$

$\mathrm{P}$

$=\frac{\text { Skor yang diperoleh }}{\text { skor maksimal }} \times 100 \%$

\section{Persamaan 1}

Hasil Validasi Ahli

\section{b. Evaluasi Propotipe}

Pada langkah evaluasi one to one yang dilaksanakan pada tanggal 20 November dengan melakukan wawancara kepada tiga orang siswa. Langkah-langkah yang dilakukan dalam evaluasi one to one yaitu: (1) siswa diminta untuk membaca dan melihat-lihat sekilas bahan ajar LKS menulis pantun, (2) siswa diminta untuk memperhatikan materi yang diambil secara acak sebagai contoh untuk ditanyakan, (3) selanjutnya siswa ditanya secara lisan tentang materi yang ada, sesuai, menarik dan mudah atau sebaliknya. Validasi one to one bahan ajar LKS menulis pantun terdapat beberapa kriteria yaitu: (a) kemenarikan bahan ajar, (b) keterbacaan isi materi, (c) penyajian gambar, dan (d) penyajian materi dalam bahan ajar LKS pantun. Evaluisi one to one ini dilakukan untuk melihat kepraktisan penggunaan bahan ajar LKS pantun. Pelaksanaan uji one to one yang dilakukan oleh tiga orang siswa yang menyatakan bahwa bahan ajar LKS pantun dapat memotivasi. Bahan ajar LKS pantun juga mendapat respon positif terkait dengan materi yang disajikan, sehingga mudah dipahami oleh siswa dalam proses pembelajaran.

\section{Pelaksanaan Evaluasi Kelompok Kecil}

Pada langkah ini siswa mengisi angket tertutup dengan soal sebanyak 10 butir. Siswa yang dipilih secara acak ini dijadikan satu baris untuk mengisi angket yang telah dibagikan. Pembelajaran dilakukan seperti pembelajaran sesungguhnya. Evaluasi kelompok kecil ini dilakukan untuk mendaptkan informasi mengenai tanggapan siswa tentang keterbacaan materi, kemenarikan bahan ajar bisa menulis puisi.

Pada evalusi kelompok kecil, angket yang diberikan kepada siswa. Babarapa jumlah pertanyaan yang akan dijawab oleh siswa, untuk mengetahui sikap siswa terhadap bahan ajar LKS pantun. Dari hasil yang didapat ada uji coba kelompok kecil mendapatkan skor 26,5\%. Hasil tersebut menunjukan bahwa nilai tersebut telah terbasuk nilai yang tinggi. Batas minimal, kuartil, median maupun kuartil 3. Pada uji coba kelompok kecil dengan menggunakan angkat tertutup telah berhasil.

Berdasarkan hasil angket uji coba kelompok kecil yang diperoleh, dapat disimpulkan bahwa respon siswa terhadap bahan ajar LKS pantun adalah sangat positif dengan persentase 91,25\%. Uji kelompok kecil bahan ajar LKS pantun sudah praktis. Langkah selanjutnya, bahan ajar LKS akan di uji cobakan di ruang lingkup yang lebih luas untuk megetahui keefektifanya.

\section{Pelaksanaan Uji Lapangan}

Tahap akhir dalam pengembangan bahan ajar, yaitu uji coba lapangan. Uji coba dilakukan pada kelas VII.3 SMP Xaverius Tugumulyo, kegiatan ini dimaksukan untuk mendapatkan informasi yang menyeluruh tentang kualitas produk bahan ajar LKS. Uji coba bahan ajar LKS dilakukan di kelas VII.3 dengan jumlah siswa 23 orang. Pelaksanaan uji coba 
lapangan untuk mengetahui kemampuan siswa dalam menulis pantun. Setelah siswa menggunakan bahan ajar LKS pantun. Berdasarkan hasil tes kemampuan menulis pantun dapat dikatakan efektif apabila mendapat nilai $\geq 72$. Uji coba lapangan ditutup dengan pemberian angket yang dilakukan setelah membahas materi dengan menggunakan bahan ajar. Angket yang diberikan terdiri dari 20 komponen pertanyaan yang bertujuan untuk mengetahui sikap siswa terhadap bahan ajar menulis pantun. Berdasarkan hasil angket uji coba kelompok besar yang diperoleh, dapat disimpulkan bahwa respon siswa terhadap bahan ajar LKS pantun adalah sangat positif dengan persentase $90,7 \%$.

\section{PEMBAHASAN}

Research \& Development atau penelitian pengembangan merupakan penelitian yang menghasilakan produk baru. Produk yang peneliti hasilkan berupa bahan ajar LKS menulis pantun. Materi yang terdapat dalam LKS tersebut adalah menulis pantun di kelas VII. Bahan ajar yang telah dikembangkan dapaat dicermati dengan seksama melalui dua apsek yang meliputi; (1) proses desain dan pengembangan bahan ajar LKS menulis pantun berbasis kearifan lokal dan (2) mengetahui valid, praktis, dan efektif bahan ajar LKS menulis pantun berbasis kearifan lokal. Kedua ulasan tersebut akan dipaparkan secarai detail sebagimana berikut.

\section{Proses Desain dan Pengembangan Bahan Ajar Menulis Pantun Berbasis Kearifan Lokal}

Proses desain pengembangan bahan ajar LKS menulis pantun dilakukan setelah tahap mengidentifikasi. Tahap mengidengtifiksi dilakukan untuk mengetahui kebutuhan bahan ajar menulis pantun. Proses mendesain bahan ajar yaitu menentukan tujuan pembuatan bahan ajar menulis pantun dan dilanjutkan eveluasi kevalidan, kepratisan, dan keefektifan bahan ajar LKS menulis pantun.

Bahan ajar LKS menulis pantun dibuat praktis untuk menarik minat belajar siswa. Di bagian cover diberikan gambar tentang kearifan lokal, begitu juga dengan bagian belakang juga diberikan warna agar terkesan lebih menarik. Kondisi yang demikian membuat daya Tarik dari bahan ajar menjadi lebih menarik siswa untuk menggunakannya (Muslich, 2010). Ilustrasi dalam bahan ajar akan memberikan tampilan yang bervariasi, sehingga lebih banyak menarik minat untuk membaca dan mempelajarinya (Pannen \& Purwanto, 2001). Tampilan bahan ajar telah didesian sesuai dengan karakteristik siswa, sehingga tidak perlu lagi ada proses adaptasi yang panjang (Haryonik \& Bhakti, 2018). Pemilihan cover pada bahan ajar LKS menulis pantun harus diperhatikan, agar bahan ajar LKS menulis pantun dapat menarik minat belajar siswa. Bahan ajar yang dibuat harus sistematis, dimulai dari bagian awal yang terdapat kualitas buku, kata pengantar, daftar isi, peta konsep kemudian dilanjutkan dengan materi (Astrini, 2013).

Keguanaan bahan ajar LKS menulis pantun berbasis kearifan lokal meliputi; (1) menarik minat siswa agar lebih termotivasi dalam pembelajaran menulis pantun, (2) sebagai panduan dalam kegiatan pembelajaran menulis pantun, (3) menumbuhkembangkan kreativitas siswa dalam pelajaran menulis pantun, (4) siswa diharapkan dapat berperan aktif dalam kegiatan pembelajaran, sehingga siswa tidak takut untuk bertanya, mengeluarkan pendapat, gagasan mengenai materi yang diajarkan.

\section{Valid, Praktis, dan Efektif Bahan Ajar Menulis Pantun}

Evaluasi kevalidan bahan ajar menulis pantun dilakukan dengan pengisian instrumen penilaian bahan ajar kepada validator ahli. Evaluasi ini dilakukan oleh tiga ahli, yaitu (1) ahli kebahasaan, (2) ahli kelayakan desain, dan (3) ahli isi/materi. Hasil angket dari para ahli merupakan standar patokan apakah bahan ajar yang dikembangkan valid atau tidak. 
Berdasarkan analisis angket validasi ahli, bahan ajar LKS pentun berbasis kearifan lokal tergolong dalam kategori baik dengan persentase $75,83 \%$.

Tabel 2

Rekapitulasi Tanggapan Ahli

\begin{tabular}{clccc}
\hline No. & Validator & Skor yang diperoleh & Persentase & Kategori \\
\hline 1 & Desain & 21 & $60 \%$ & Valid \\
\hline 2 & Kebahasaan & 42 & $84 \%$ & Valid \\
\hline 3 & Materi & 28 & $80 \%$ & Valid \\
\hline & Total & 91 & $75,83 \%$ & Valid \\
\hline
\end{tabular}

Berdasarkan hasil penelitian dapat buktikan bahwa bahan ajar LKS menulis pantun berbasis kearifan lokal yang dikembangkan telah valid. Bahan ajar selanjutnya direvisi sesuai dengan saran-saran dan masukan dari validasi ahli. Setelah diketahui kevalidannya bahan ajar diuji cobakan di kelas VII.3 SMP Xaverius Tugumulyo.

Kepraktisan bahan ajar LKS pantun berbasis kearifan lokal juga dapat dilihat dengan evaluasi one to one dan evaluasi kelompok kecil. Pembeda dari evalusi one to one dan uji kelompok kecil yaitu dalam bentuk pertanyaan. Evaluasi one to one berupa wawancara kepada 3 siswa, sedangkan kelompok kecil berbentuk angket yang terdiri dari 10 butir pertanyaan dengan 6 siswa. Angket yang dibagikan mengandung sejumlah pertanyaaan tentang kepraktisan penggunaan bahan ajar LKS menulis pantun berbasis kearifan lokal. Bahan ajar yang telah dievalusi uji one to one dari tiga orang siswa, mendapatkan respon yang sangat positif. Kemudian uji coba kelompok kecil berjumlah 6 orang, didapatkan hasil yang tergolong baik dengan persentase $91,25 \%$. Dengan persentase tersebut berarti bahan ajar LKS menulis pantun berbasis kearifan lokal sudah praktis untuk digunakan.

Evaluasi keefektifan bahan ajar dapat dilihat dari nilai tes menulis pantun. Nilai siswa dikatakan baik apabila mendapatkan nilai $\geq 72$. Rata-rata nilai tes menulis pantun sesudah menggunakan bahan ajar LKS menulis pantun berbasis kearifan lokal 80,52, dan hanya 4 siswa yang di bawah 72. Sebelum menggunakan bahan ajar, nilai siswa belum mencapai KKM, dengan nilai rata-rata 62,87 dan setelah menggunakan bahan ajar LKS menulis pantun nilai rata-rata siswa menjadi 80,52. Penghitungan validitas insterumen sangat tinggi dan mampu mengukur apa yang diinginkan dengan hasil 0,98 yang dikategorikan validitas sangat tinggi.

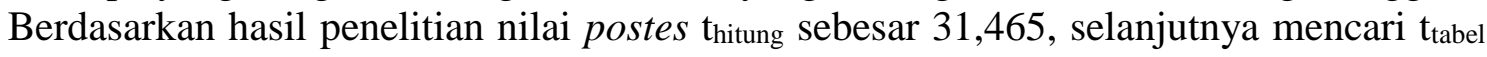
dengan tabel nilai-nilai dalam distribusi t. Taraf signifikan $\alpha=0,05$ dan derajat kebebasan $(\mathrm{dk}=\mathrm{df}) 22$, maka diketahui $\mathrm{t}_{\text {tabel }}=2,074$. Berdasarkan kriteria pengujiannya yaitu jika thitung $\geq$ $t_{\text {tabel }}$ berarti Ho ditolak dan Ha diterima, begitupun sebaliknya jika $t_{\text {hitung }}<t_{\text {tabel }}$ berarti Ho diterima dan Ha ditolak. Berdasarkan penghitungan di atas yaitu $t_{\text {hitung }} \geq t_{\text {tabel }}(31,465 \geq 2,074)$ menunjukkan bahwa Ho ditolak dan Ha diterima, berarti terdapat hubungan positif yang signifikan antara bahan ajar LKS menulis pantun berbasis kearifan lokal dengan hasil belajar menulis pantun siswa kelas VII.3 SMP Xaverius Tugumulyo, dengan signifikan sebesar 0,0001 yang berarti lebih kecil dari 0,05 , maka terjadi hubungan yang signifikan.

Berdasarkan penghitungan reliabilitas instrumen diketahui varians butir 35,49, sedangkan varians total 59,94, maka reliabilitas instrumen bahan ajar menulis pantun didapatkan dengan nilai 0,55. Langkah terakhir yaitu menghitung efektif tidaknya bahan ajar menulis pantun melalui paired sample uji-t dengan SPSS versi 20. Berdasarkan hasil uji paired samples uji-t diperoleh mean atau nilai rata-rata hasil belajar sesudah yaitu 80,5217, sedangkan nilai rata-rata hasil belajar sebelum sebesar 63,1739. Jumlah responden atau siswa yang dijadikan sampel sebanyak 23 siswa. Hubungan dari nilai rata-rata sebelum dan sesudah diperoleh 0,0001 yang berarti lebih kecil dari alpha value $(0,05)$, maka berdasarkan 
pengambilan keputusan dari uji correlations menunjukan adanya hubungan yang signifikan antara data nilai rata-rata sesudah dan nilai rata-rata sebelum menggunakan bahan ajar LKS pantun berbasis kearifan lokal.

Nilai mean atau nilai rata-rata sebelum dan sesudah sebesar 17,34783 dengan Sig. (2tailed) sebesar 0,0001 <0,05. Karena nilai Sig. (2-tailed) diperoleh 0,0001 lebih kecil dari alpha value yaitu 0,05 , maka kesimpulannya adalah terdapat perbedaan yang signifikan antara sebelum dan sesudah menggunakan bahan ajar LKS menulis pantun berbasis kearifan lokal yang peneliti kembangkan. Berdasarkan kesimpulan tersebut, maka penggunaan bahan ajar LKS menulis pantun berbasis kearifan lokal sudah valid, praktis, dan efektif.

\section{SIMPULAN}

Hasil evaluasi bahan ajar LKS menulis pantun berbasis kearifan lokal dilakukan oleh tiga ahli, yaitu (1) ahli kebahasaan, (2) ahli kelayakan desain, dan (3) ahli isi/materi. Berdasarkan analisis angket validasi ahli, bahan ajar LKS menulis pantun tergolong dalam kategori baik dengan persentase 75, 83\%, Dari hasil tersebut dinyatakan bahan ajar telah valid. Kepraktisan bahan ajar juga dapat dilihat dengan evaluasi one to one kepada 3 siswa dalam bentuk wawancara dan evaluasi kelompok kecil. Bahan ajar yang telah dievalusi oleh uji one to one dari tiga orang dan kelompok kecil berjumlah 6 orang dapat diketahui tergolong baik dengan persentase $91,25 \%$.

Menunjukan nilai postes $t_{\text {hitung }}$ sebesar 31,465 , selanjutnya mencari $t_{\text {tabel }}$ dengan tabel nilai-nilai dalam distribusi t. Taraf signifikan $\alpha=0,05$ dan derajat kebebasan ( $\mathrm{dk}=\mathrm{df}$ ) 22, maka diketahui $t_{\text {tabel }}=2,074$. Berdasarkan kriteria pengujiannya yaitu jika $t_{\text {hitung }} \geq t_{\text {tabel }}$ berarti Ho ditolak dan Ha diterima, begitupun sebaliknya jika $t_{\text {hitung }}<t_{\text {tabel }}$ berarti Ho diterima dan Ha ditolak. Berdasarkan penghitungan tersebut yaitu $t_{\text {hitung }} \geq t_{\text {tabel }}(31,465 \geq 2,074)$ menunjukkan bahwa Ho ditolak dan Ha diterima, berarti terdapat hubungan positif yang signifikan antara bahan ajar LKS menulis pantun berbasis kearifan lokal dengan hasil belajar menulis pantun siswa kelas VII.3 SMP Xaverius Tugumulyo. Dengan Signifikan sebesar 0,0001 yang berarti lebih kecil dari 0,05, maka terjadi hubungan yang signifikan. Dengan demikian bahan ajar bisa menulis pantun telah, valid, praktis dan efektif.

\section{DAFTAR PUSTAKA}

Aji, W. N. (2016). Model Pembelajaran Dick and Carrey dalam Pembelajaran Bahasa dan Sastra Indonesia. Kajian Linguistik dan Sastra, 1(2), 119-126.

Arsanti, M. (2018). Pengembangan Bahan Ajar Mata Kuliah Penulisan Kreatif Bermuatan Nilai-Nilai Pendidikan Karakter Religius bagi Mahasiswa Prodi PBSI, FKIP, UNISSULA. KREDO: Jurnal Ilmiah Bahasa dan Sastra, 1(2).

Astrini, L. (2013). Pengembangan Bahan Ajar Menulis Petunjuk bagi Pembelajaran dengan Pendekatan Kontekstual pada Siswa SMP. Universitas Negeri Semarang.

Erianjoni, E. (2018). Pengembangan Materi Ajar Sosiologi tentang Mitigasi Bencana Berbasis Kearifan Lokal di Kota Padang SOCIUS, 4(2), 97-108.

Haryonik, Y., \& Bhakti, Y. B. (2018). Pengembangan Bahan Ajar Lembar Kerja Siswa dengan Pendekatan Matematika Realistik. MaPan: Jurnal Matematika dan Pembelajaran, 6(1), 40-55.

Hidayat, M. T. (2018). Pengembangan Bahan Ajar Menulis Pantun Menggunakan Media Mencari Pasangan Kartu pada Siswa Kelas VII SMP Negeri 12 Langsa. Jurnal Samudra Bahasa, 1(2), 64-73. 
Khoirotunnisa, R. P., Hasanah, M., \& Dermawan, T. (2018). Pengembangan Bahan Ajar Menulis Pantun Bermuatan Nilai Budaya dengan Strategi Pohon Kata untuk Siswa Kelas VII. Jurnal Pendidikan: Teori, Penelitian, dan Pengembangan, 3(2), 238-244.

Muslich, M. (2010). Text Book Writing: Dasar-Dasar Pemahaman, Penulisan, dan Pemakaian Buku Teks. Yogjakarta: Ar-Ruzz Media.

Pannen, P., \& Purwanto. (2001). Penulisan Bahan Ajar. Jakarta: Pusat Antar-Universitas untuk Peningkatan dan Pengembangan Aktivitas Intruksional Direktorat Jenderal Perguruan Tinggi.

Prasaja, F. D. D. P. (2016). Pengembangan Bahan Ajar Modul Menulis Teks Cerpen Berdasarkan Teknik Storyboard untuk Siswa SMA/MA Kelas XI. Pend. Bahasa dan Sastra Indonesia-S1, 5(5), 23-34.

Qomario, Q., \& Agung, P. (2018). Pengembangan Lembar Kerja Siswa (LKS) IPA Berbasis ICT sebagai Media Pembelajaran Terampil: Jurnal Pendidikan dan Pembelajaran Dasar, 5(2), 239-246.

Sagita, D. (2018). Peran Bahan Ajar LKS untuk Meningkatkan Prestasi Belajar Matematika Paper presented at the Seminar Nasional Pendidikan Matematika Ahmad Dahlan.

Sugiarto, E. (2011). Siap Ujian Bahasa Indonesia Khusus Puisi Lama. Yogyakarta: Khitah Publishing.

Sugiyono, P. (2014). Metode Penelitian Kuantitatif dan Kualitatif dan R\&D. Bandung: Alfabeta.

Sulton, A. (2016). Antara Fiksi dan Sejarah: Kapitalisasi Kondisi Sosial, Ekonomi, dan Politik dalam Novel Rasa Merdika. Paramita, 26(1), 72-85.

Tafifin, M. (2017). Kemampuan Menulis Pantun Siswa Kelas VII SMP Negeri 52 Konawe Selatan JURNAL HUMANIKA, 3(15), 1-12.

Yaumi, M. (2016). Prinsip-Prinsip Desain Pembelajaran. Jakarta: Kencana Prenada Media Group. 